\title{
THE DEVELOPMENTAL PATTERN OF HOMOLOGOUS AND HETEROLOGOUS tRNA METHYLATION IN RAT BRAIN DIFFERENTIAL EFFECT OF SPERMIDINE ${ }^{1}$
}

\author{
C. E. Salas, C. J. Cummins, and O. Z. Sellinger \\ Laboratory of Neurochemistry, Mental Health Research Institute \\ University of Michigan Medical Center, Ann Arbor, Michigan 48109
}

Accepted March 31, 1976

\begin{abstract}
Using $S$-adenosyl-L- $\left[\mathrm{Me}^{-14} \mathrm{C}\right]$ methionine, rat cerebral cortex methyltransferase activity was determined during the early postnatal period in the absence of added Escherichia coli tRNA and in its presence. [Me- ${ }^{14} \mathrm{C}$ ] $\mathrm{tRNA}$ was purified from both systems and its $\left[\mathrm{Me}-{ }^{14} \mathrm{C}\right]$ base composition determined. The endogenous formation of $\left[\mathrm{Me}-{ }^{14} \mathrm{C}\right]$ tRNA (homologous tRNA methylation) was totally abolished in the presence of $2.5 \mathrm{mM}$ spermidine, whereas $E$. coli $B$ tRNA methylation (heterologous methylation) was markedly stimulated. Only $\left[\mathrm{Me}-{ }^{14} \mathrm{C}\right]$ 1-methyl guanine and $\left[\mathrm{Me}^{14} \mathrm{C}\right] N^{2}$-methyl guanine were formed by homologous methylation, there being an inverse shift in their relative proportions with age. Heterologous tRNA methylation led, additionally, to the formation of [Me- $\left.{ }^{14} \mathrm{C}\right]$ $\mathrm{N}_{2}^{2}$-dimethyl guanine, 5-methyl cytosine, 1-methyl adenine, 5-methyl uracil, 2methyl adenine, and 1-methyl hypoxanthine. A comparison of heterologous tRNA methylation between the whole brain cortex (containing nerve and glial cells) and bulk-isolated nerve cell bodies revealed markedly lower proportions of [Me- $\left.{ }^{14} \mathrm{C}\right] N_{2}$-methyl and $N_{2}^{2}$-dimethyl guanine and significantly higher proportions of $\left[\mathrm{Me}^{11} \mathrm{C}\right] 1$-methyl adenine in the neurons. The present findings suggest (1) that homologous tRNA methylation may provide developing brain cells with continuously changing populations of tRNA and (2) that neurons are enriched in adenine residue-specific tRNA methyltransferases that are highly sensitive to spermidine.
\end{abstract}

${ }^{1}$ This research was supported by grant NS-06294 of the United States Public Health Service. 


\section{INTRODUCTION}

In the past few years, mammalian tRNA methyltransferases have been the subject of considerable interest because of their suggested role in the processes of cell differentiation, viral infection, and tumorigenesis (1-3). Nonetheless, researchers have encountered many difficulties in attempting to purify and characterize base residue-specific tRNA methyltransferases or sufficient amounts of tRNA to allow a thorough biochemical analysis of the properties and specificities of this complex family of enzymes. Most of the information gathered to date refers to methylations studied in heterologous systems in which mammalian enzymes methylate $E$. coli (4) or yeast (5) tRNA's.

The transfer of methyl groups from $S$-adenosyl-L-methionine to heterologous tRNA has been observed to occur in high-speed supernatants prepared from brains of young animals (6-9), yet the properties of the enzymes catalyzing this transfer have not been studied in detail.

In a most recent study, Johnson et al. (9) compared these activities in neonatal and adult whole mouse brain, while we demonstrated homologous methylation of tRNA in rat brain (10) and showed the resulting $\left[\mathrm{Me}-{ }^{14} \mathrm{C}\right]$ tRNA to contain chiefly $\left[\mathrm{Me}-{ }^{14} \mathrm{C}\right] 1-$ methyl guanine and [Me$\left.{ }^{14} \mathrm{C}\right] N^{2}$-methyl guanine $(10,11)$.

The polyamine spermidine is widely distributed among living systems (12), and its involvement in a large number of biological processes is well documented (12-14). For brain tissue, Seiler and associates $(15,16)$ have recently shown that changes in regional spermidine concentrations during development relate closely to concomitant tRNA changes. Effects of spermidine on tRNA methylation $(12,13)$ and aminoacylation (17-22) have also been reported, but none in brain. In the present study, we compare the effects of spermidine on tRNA methylation by tRNA methyltransferases of the developing rat brain cortex and, in an effort to assess the cell-specific nature of the process, of bulk-isolated nerve cell bodies (23) as well.

\section{EXPERIMENTAL PROCEDURE}

The $S$-adenosyl-L-[Me- $\left.{ }^{14} \mathrm{C}\right]$ methionine (sp act $57 \mathrm{mCi} / \mathrm{mmol}$ ) was from $\mathrm{New}$ England Nuclear, the methylated bases from Sigma Chemical Co. (St. Louis, Missouri) or Cyclo Corp. (Los Angeles, California), and $E$. coli $B$ tRNA (mol wt 25,000) from Schwarz-Mann (Orangeburg, New York). Precoated cellulose plates with fluorescent indicator No. 6065 were from Eastman Kodak Co. (Rochester, New York), spermidine phosphate from ICN Biochemicals (Cleveland, Ohio), and DEAE Cellulose (Whatman No. 52, microgranular) from Reeve, Angel Co. (Clifton, New Jersey). Pancreatic ribonuclease was from Wor- 
thington Co., Freehold, New Jersey. All other solvents and reagents were of the best grade available. Phenol was distilled before use.

\title{
Preparation of Methyltransferases of Rat Cerebral Cortex
}

Cerebral cortices were obtained from male Sprague-Dawley rats, decapitated at the ages specified in the text. They were homogenized in 3.5 vol ice-cold $10 \mathrm{mM}$ Tris- $\mathrm{HCl}$ buffer, pH 7.5, containing $1 \mathrm{mM}$ dithiothreitol and $0.1 \mathrm{mM}$ Na-EDTA. All subsequent operations were at $4^{\circ} \mathrm{C}$. The homogenates were centrifuged at $165,000 \mathrm{~g}$ for $4 \mathrm{hr}$, and the clear supernatant was used as the source of the methyltransferases.

\section{Measurement of Methyltransferase Activity}

\begin{abstract}
"Rate" Methylation assay. The assay was as described by Pegg (4), the incubation mixture containing, in a total volume of $0.15 \mathrm{ml}: 15 \mu \mathrm{mol}$ Tris- $\mathrm{HCl}, \mathrm{pH} 8.6 ; 0.05 \mu \mathrm{mol} \beta$ mercaptoethanol, $7 \mathrm{nmol} S$-adenosyl-L-[Me- $\left.{ }^{14} \mathrm{C}\right]$ methionine; $0.4 \mathrm{nmol} E$. coli $B$ tRNA (when required); and $0.2-0.3 \mathrm{mg}$ brain protein. The mixture was incubated at $37^{\circ} \mathrm{C}$, and at intervals portions were withdrawn and placed on disks of Whatman No. 1 filter paper previously moistened with 5\% TCA (24). The disks were processed according to Pegg (4) and their radioactivity determined in a Unilux 11 spectrometer.

"Extent" Methylation Assay (4) The incubation mixture contained, in a final volume of $1 \mathrm{ml}: 100 \mu \mathrm{mol}$ Tris-HCl, pH 8.3; $50 \mu \mathrm{mol} \mathrm{Na-EDT} \mathrm{A;} 1 \mu \mathrm{mol}$ dithiothreitol; $300 \mu \mathrm{mol}$ ammonium acetate; $10 \mathrm{nmol} S$-adenosyl-L-[Me- $\left.{ }^{14} \mathrm{C}\right]$ methionine; $0.4-0.8 \mathrm{nmol} E$. coli $B$ tRNA (when required); and 2.5-3.0 mg brain protein. Incubation was at $37^{\circ} \mathrm{C}$ for $45 \mathrm{~min}$, and the reaction was stopped by the addition of $1 \mathrm{vol} 88 \%$ phenol in $0.1 \mathrm{M}$ sodium acetate, pH 5.1. After phenol extraction and the addition of $100 \mu \mathrm{g}$ carrier $E$. coli $B$ tRNA, tRNA was precipitated from the aqueous phase by the addition of $2.5 \mathrm{vol}$ absolute ethanol, and the suspension was allowed to stand at $-20^{\circ} \mathrm{C}$ overnight. The tRNA was collected by centrifugation and washed twice with $67 \%$ ethanol in $0.1 \mathrm{M}$ sodium acetate, $\mathrm{pH} \mathrm{5.1}$. The final pellet was suspended in water, transferred to a Carius tube 25 (l) $\times 1.5$ (d) cm, and the contents were lyophilized. The residue was suspended in $1 \mathrm{ml}$ trifluoroacetic acid, and the Carius tube was sealed and its contents subjected to hydrolysis according to Klagsbrun (1). After the Carius tube was opened at room temperature, the trifluoroacetic acid was removed under a stream of $\mathrm{N}_{2}$ at $30^{\circ} \mathrm{C}$ and the dry residue suspended in about $10 \mu \mathrm{l}$ water.
\end{abstract}

\section{Thin-Layer Chromatography of the Methylated Bases}

The procedure was that of Klagsbrun (1). Cellulose plates $(20 \times 20 \mathrm{~cm})$ were spotted and chromatographed in the first direction in methanol:conc. $\mathrm{HCl}$ : water $(70: 20: 10)$; the plates were dried at room temperature for at least $3 \mathrm{hr}$ and chromatographed in the second direction in $n$-butanol:gl. acetic acid:water $(68: 17: 17)$. The front of the solvent was allowed to rise to $14 \mathrm{~cm}$. The plates were autoradiographed on X-ray film, type RB-54 (Eastman Kodak, Rochester, New York), with an exposure time of 17-27 days; the radioactive areas were scraped off, suspended in $1 \mathrm{ml}$ distilled water and, after sonication for $10 \mathrm{~min}$, centrifuged at $3,000 \mathrm{~g}$ for $10 \mathrm{~min}$. The clear solution was concentrated by freeze-drying and replated together with authentic $\left[{ }^{12} \mathrm{C}\right]$ markers for TLC as described above. 7-Methyl guanine was effectively separated from 1-methyl guanine by repeating the TLC development in the second solvent. The radioactivity contained in the TLC scrapings was determined after mixing with $10 \mathrm{ml}$ Scintisol Complete (Isolab., Inc., Akron, Ohio). 
Methylated Albumin Kieselguhr (MAK)

MAK columns were prepared according to Mandell and Hershey (25).

\section{Preparation of Nerve Cell Bodies}

The procedure has been described in detail elsewhere (23). To prepare the neuronal high-speed supernatant, the nerve cell bodies were homogenized in $3 \mathrm{vol} 10 \mathrm{mM}$ Tris- $\mathrm{HCl}$ buffer, pH 7.5, containing $1 \mathrm{mM}$ dithiothreitol and $0.1 \mathrm{mM}$ EDTA (disodium), and the homogenate was centrifuged at $165,000 \mathrm{~g}$ for $3 \mathrm{hr}$.

\section{Analytical}

Protein was determined by the procedure of Lowry et al. (26).

\section{RESULTS}

\section{Effect of Time and of Protein Concentration}

The time course of endogenous and total methylation was found to be significantly slower for the former process. Moreover, while total methylation proceeded virtually linearly with time, the progress of endogenous methylation ceased to be linear past $15 \mathrm{~min}$ of incubation. The incorporation of $\left[\mathrm{Me}^{-14} \mathrm{C}\right]$ groups into acid-precipitable products was found to be linear over a $20-300 \mu \mathrm{g} /$ tube range of protein concentrations. This linearity held whether incubation was short $(7 \mathrm{~min})$ or long (45 $\mathrm{min})$.

\section{Effects of Spermidine and Cell Type}

As shown in Fig. 1, spermidine inhibited the endogenous methylation in both the whole brain cortex and the isolated nerve cell bodies, yet it markedly stimulated methylation in the presence of $E$. coli $B$ tRNA irrespective of the cellular source of the methyltransferases.

\section{Effect of Spermidine and Dialysis as a Function of Age}

We determined the effect of spermidine on endogenous and total methylation at four times during early postnatal brain development. The results of these experiments (Fig. 2) indicate a uniform decrease of both methylation processes with age. The figure also shows that spermidine inhibited endogenous methylation to the greatest extent at 3 days, i.e., 


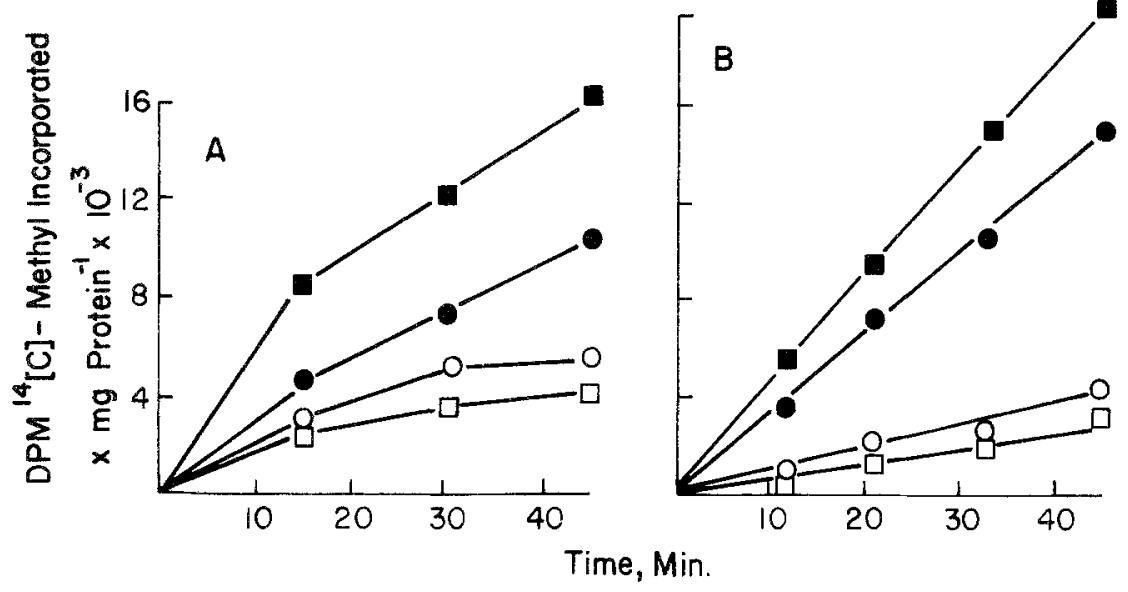

Fig. 1. Effect of spermidine on endogenous and total methylation. Brain cortex methyltransferase, 8 days old, were "rate" assayed (4); $35 \mu 1$ incubation mixture was withdrawn at intervals and processed as indicated (see Experimental Procedure) (A) Enzymes derived from whole brain cortex; (B) enzymes derived from nerve cell bodies (23). $0---0$ : endogenous methylation; $\square$---- $\square$ : endogenous methylation in the presence of $2.5 \mathrm{mM}$ spermidine; -- $10 \mu \mathrm{g} E$. coli $B$ tRNA was added to the incubation mixture; as -----, plus $2.5 \mathrm{mM}$ spermidine. Values represent averages of 3 determination with less than $10 \%$ variation.

when this process exhibited maximal rates, while it stimulated total methylation rather uniformly over the entire age period examined.

Further confirmation that methylation decreased with age was obtained in experiments using extensively dialyzed preparations of cortical methyltransferases. The results in Table I show that: (1) all forms of methylation, with or without spermidine and before or after dialysis, decreased with age; (2) following dialysis, the inhibition by spermidine of endogenous methylation could no longer be demonstrated; and (3) after day 3 and irrespective of dialysis, the methylation of $E$. coli $B$ tRNA became totally dependent on the presence of spermidine.

\section{Nature of the $\left[\mathrm{Me}-{ }^{14} \mathrm{C}\right]$ Products Formed by Endogenous Methylation}

Figure 3 illustrates the sensitivity toward ribonuclease of the methylatable substrates present in brain high-speed supernatants. In these experiments, $20 \mu \mathrm{g}$ ribonuclease was preincubated with brain supernatant at $37^{\circ} \mathrm{C}$ for $30 \mathrm{~min}$, at which time $S$-adenosyl-L-[Me- $\left.{ }^{14} \mathrm{C}\right]$ methionine (see Experimental Procedure) was added and the tubes reincubated, as 


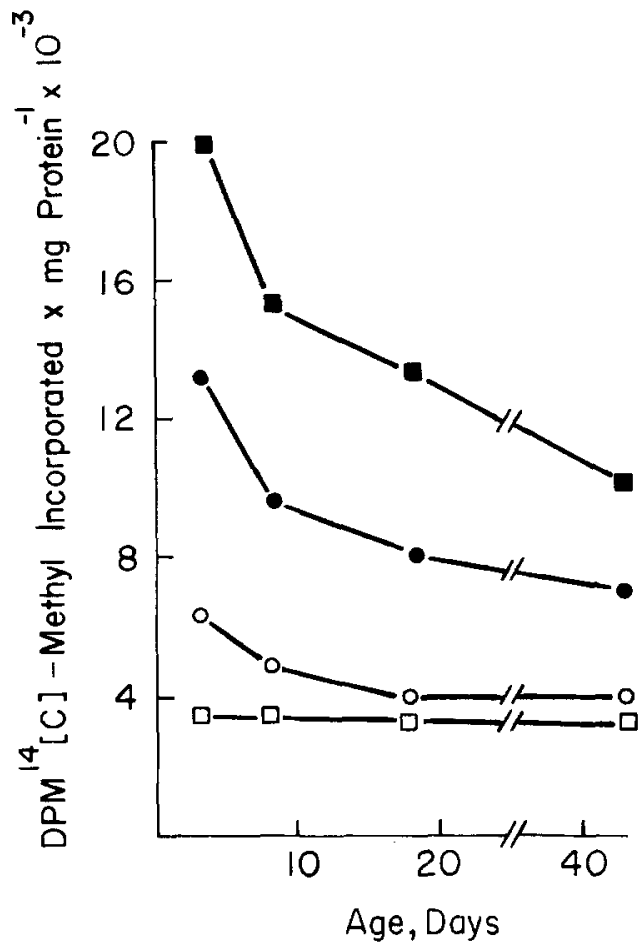

FIG. 2. Age-dependent changes in methylation: spermidine effect. Brain cortex methyltransferases, 3, 8, 18, and 43 days old, were "rate" assayed (4) (see Experimental Procedure). The incubation time was $30 \mathrm{~min}$. $\mathrm{O}--\mathrm{O}$ : endogenous methylation; $\square----\square$ : endogenous methylation in the presence of $2.5 \mathrm{mM}$ spermidine; $---10 \mu \mathrm{g} \mathrm{E}$. coli $B$ tRNA was added to the incubation mixture; $\mathbf{- - - -}$ : as ------, plus $2.5 \mathrm{mM}$ spermidine.

indicated. Significantly less (about 30\%) acid-insoluble radioactivity than in controls was noted, a finding that demonstrated the formation of homologous $\left[\mathrm{Me}^{14} \mathrm{C}\right]$ tRNA in the ribonuclease-free tubes. To obtain further evidence for homologous $\left[\mathrm{Me}^{-14} \mathrm{C}\right] \mathrm{tRNA}$ formation, we chromatographed the phenol-extracted $\left[\mathrm{Me}^{-14} \mathrm{C}\right]$ products on methylated albumin kieselguhr (MAK) (25) (Fig. 4) or, alternatively, on DEAE cellulose (27) (Fig. 5). The MAK elution profile revealed substantial amounts of radioactivity under the $A_{254}$ peak of the $E$. coli $B$ tRNA (tubes 12-16) added as carrier immediately before chromatography. Homologous [Me$\left.{ }^{14} \mathrm{C}\right] \mathrm{tRNA}$ was also separated from nucleotides and proteins by DEAE cellulose chromatography (27). As may be seen (Fig. 5B), with spermidine but no $E$. coli $B$ tRNA present during the incubation, virtually no radioactivity was associated with the carrier tRNA peak; conversely, 
TABLE I

Effect of Dialysis and Spermidine on Cerebral Methylation as a Function of EARly Postnatal AgE ${ }^{a}$

\begin{tabular}{|c|c|c|c|c|c|c|}
\hline \multicolumn{4}{|c|}{$-E$. coli tRNA } & \multicolumn{3}{|c|}{+ E. coli $\mathrm{tRNA}^{b}$} \\
\hline Spermidine: & - & - & + & - & - & + \\
\hline $\begin{array}{c}\text { Age } \\
\text { (days) }\end{array}$ & $\begin{array}{l}\text { Before } \\
\text { dialysis }\end{array}$ & & & $\begin{array}{l}\text { Before } \\
\text { dialysis }\end{array}$ & & \\
\hline 3 & 1.41 & 0.92 & 1.33 & 0.83 & 0.19 & 5.43 \\
\hline 5 & 0.51 & 0.58 & 0.91 & 0.04 & 0.02 & 3.84 \\
\hline 10 & 0.33 & 0.50 & 0.74 & 0.11 & - & 3.10 \\
\hline 17 & 0.35 & 0.49 & 0.57 & 0.15 & - & 1.90 \\
\hline
\end{tabular}

${ }^{a}$ From 3 to 5 rats were decapitated, and the brains were removed rapidly. Cortices were hand-dissected on ice and homogenized in 3 vol of a medium consisting of $0.25 \mathrm{M}$ sucrose, $0.5 \mathrm{mM} \beta$-mercaptoethanol, $0.1 \mathrm{mM}$ Na-EDT A, and $10 \mathrm{mM}$ Tris-HCl buffer, $\mathrm{pH}$ 7.8. The homogenate was centrifuged at $100,000 \mathrm{~g}$ for $1 \mathrm{hr}$ and the resulting supernatant used. For those experiments in which dialyzed enzyme was used, aliquots of the supernatant were dialyzed in 4 liters $10 \mathrm{mM}$ Tris- $\mathrm{HCl}, \mathrm{pH} 7.5$, containing $1 \mathrm{mM} \beta$ mercaptoethanol and $0.1 \mathrm{mM} \mathrm{Na}-\mathrm{EDTA}$, at $4^{\circ} \mathrm{C}$ for $18-24 \mathrm{hr}$. Spermidine, when added, was $2.5 \mathrm{mM}$. The methyltransferase activity was determined by the "rate" procedure of Pegg (4). Values are expressed in nmol $\left[\mathrm{Me}^{-14} \mathrm{C}\right] / \mathrm{mg}$ protein per $30 \mathrm{~min}$.

${ }^{b}$ Calculated by subtracting $-E$. coli $\mathrm{tRNA}$ values from total methylation values.

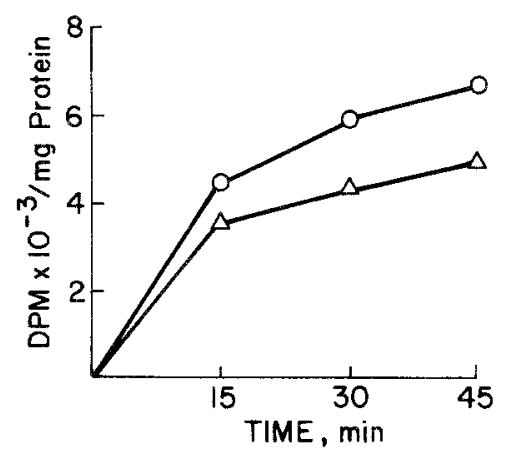

Fig. 3. Effect of ribonuclease on endogenous methylation. To one of a pair of cortical highspeed supernatant aliquots prepared from 8-day-old animals was added $20 \mu \mathrm{g}$ pancreatic ribonuclease, and both tubes were kept at $37^{\circ} \mathrm{C}$ for $20 \mathrm{~min}$. To both tubes was then added 7 nmol $S$-adenosyl-L-[Me- $\left.{ }^{14} \mathrm{C}\right]$ methionine, and incubation was continued as indicated. $\mathrm{O}--\mathrm{O}$ : ribonuclease-free; $\Delta---\Delta$ : after addition of ribonuclease. Values represent averages of 3 experiments with less than $10 \%$ variation. 


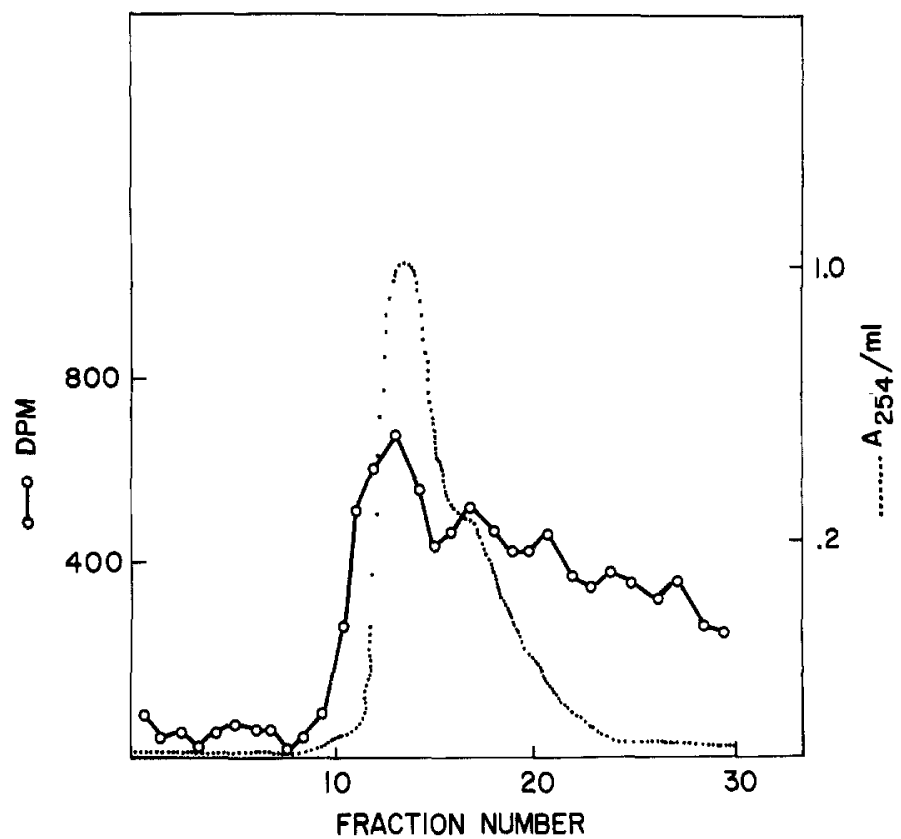

Fig. 4. Methylated albumin kieselguhr chromatography of the $\left[\mathrm{Me}^{14} \mathrm{C}\right]$ products formed by endogenous methylation. The column 2 (d) $\times 10(\mathrm{l}) \mathrm{cm}$, was prepared as described (25) and equilibrated with $0.2 \mathrm{M} \mathrm{NaCl}$ in $0.05 \mathrm{M}$ sodium phosphate, pH 7.0. The $\left[\mathrm{Me}^{\left.-{ }^{14} \mathrm{C}\right]}\right.$ products formed in the incubation were phenolized and ethanol-precipitated in the presence of $E$. coli tRNA added as carrier. Elution of the column was with $0.4 \mathrm{M} \mathrm{NaCl}$, and $4-\mathrm{ml}$ fractions were collected. Note $\log$ scale on the ordinate axis.

TABLE II

Changes with Age of the Relative Distribution of $\left[\mathrm{Me}-{ }^{14} \mathrm{C}\right] 1 \mathrm{MeThyl}$ GuANINE AND $\left[\mathrm{Me}^{-14} \mathrm{C}\right] \mathrm{N}^{2}$-Methyl Guanine in Homologously Methylated tRNA ${ }^{a}$

\begin{tabular}{cccc}
\hline \multirow{2}{*}{$\begin{array}{c}\text { Age } \\
\text { (days) }\end{array}$} & \multicolumn{3}{c}{ Total radioactivity recovered (\%) } \\
\cline { 2 - 4 } & 1-Methylguanine & $N^{2}$-Methylguanine & N.I. $^{b}$ \\
\hline 3 & 52 & 20 & 28 \\
8 & 23 & 45 & 32 \\
18 & 19 & 53 & 28 \\
\hline
\end{tabular}

"The "extent" methylation assay (4) and the conditions of thinlayer chromatography (1) are described in Methods and Materials.

${ }^{b}$ Not identified. 

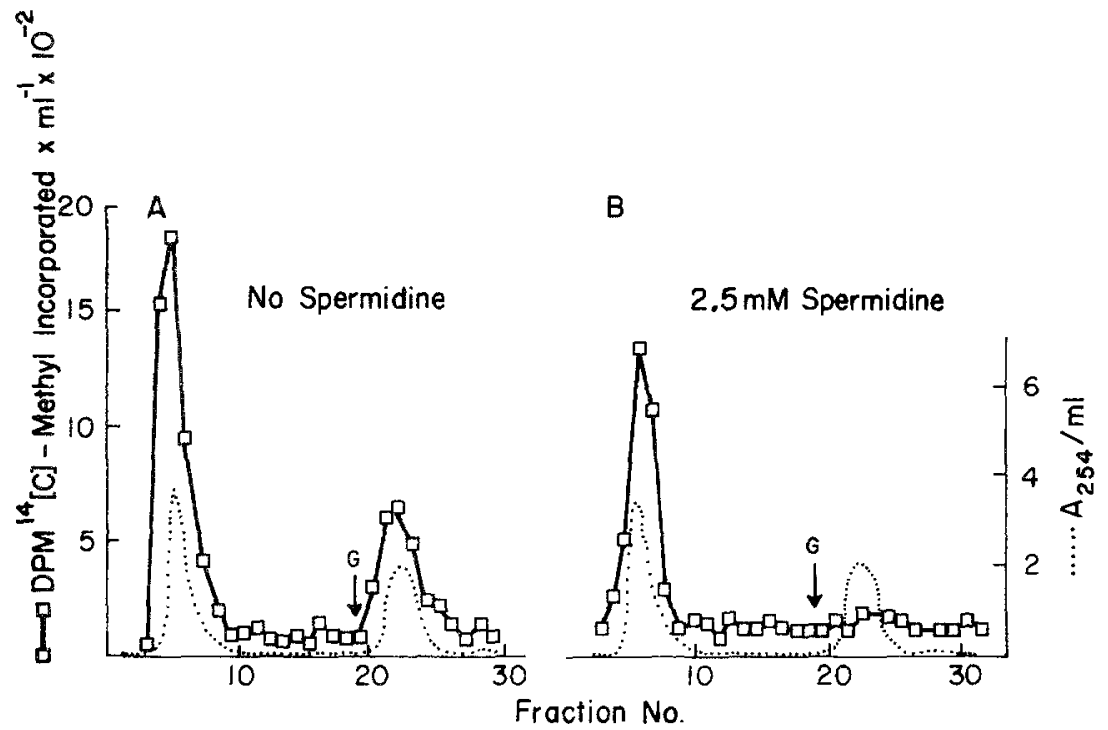

FIG. 5. DEAE-cellulose chromatography of the $\left[\mathrm{Me}^{-14} \mathrm{C}\right]$ products formed by endogenous methylation. The phenolized $\left[\mathrm{Me}^{-14} \mathrm{C}\right]$ products obtained in a "total extent" methylation assay (4) using 8-day-old brain supernatant as the source of tRNA methyltransferases were loaded on a column, 1 (d) $\times 3$ (l) $\mathrm{cm}$, which was equilibrated with $0.1 \mathrm{M} \mathrm{Na}$ acetate, $\mathrm{pH}$ 5.0. The column was washed with $0.3 \mathrm{M} \mathrm{NaCl}$ in the same buffer. tRNA $\left(\left[\mathrm{Me}-{ }^{14} \mathrm{C}\right]+E\right.$. coli) was eluted with a $60-\mathrm{ml}$ gradient, $0.3-1.0 \mathrm{M} \mathrm{NaCl}$, in the buffer described above. Radioactivity was determined on $0.1-\mathrm{ml}$ aliquots of each collected fraction. Spermidine: $2.5 \mathrm{mM}$.

when incubations contained $E$. coli $B$ tRNA, the presence of spermidine (Fig. $6 \mathrm{~B}$ vs $6 \mathrm{~A}$ ) resulted in increased amounts of radioactivity under this peak. When the contents of tubes 20-25 (shown in Figs. 5A and 5B) were hydrolyzed and the resulting bases chromatographed, no radioactivity was derived from the run shown in Fig. 5B; fractions derived from the spermidine-free incubations (Fig. 5A), on the contrary, yielded [Me$\left.{ }^{14} \mathrm{C}\right]$ 1-methyl guanine and $\left[\mathrm{Me}^{-14} \mathrm{C}\right] N^{2}$-methyl guanine, in agreement with our previous findings $(10,11)$.

\section{Effect of Age on Homologous $\left[\mathrm{Me}^{-14} \mathrm{C}\right] \mathrm{tRNA}$ Formation}

Table II shows that 1-methyl guanine and $N^{2}$-methyl guanine were the only homologous $\left[\mathrm{Me}^{-1}{ }^{14} \mathrm{C}\right]$ tRNA bases formed at 8 , as well as at 3 and 18 , days. A quantitative evaluation of their relative proportions as a 


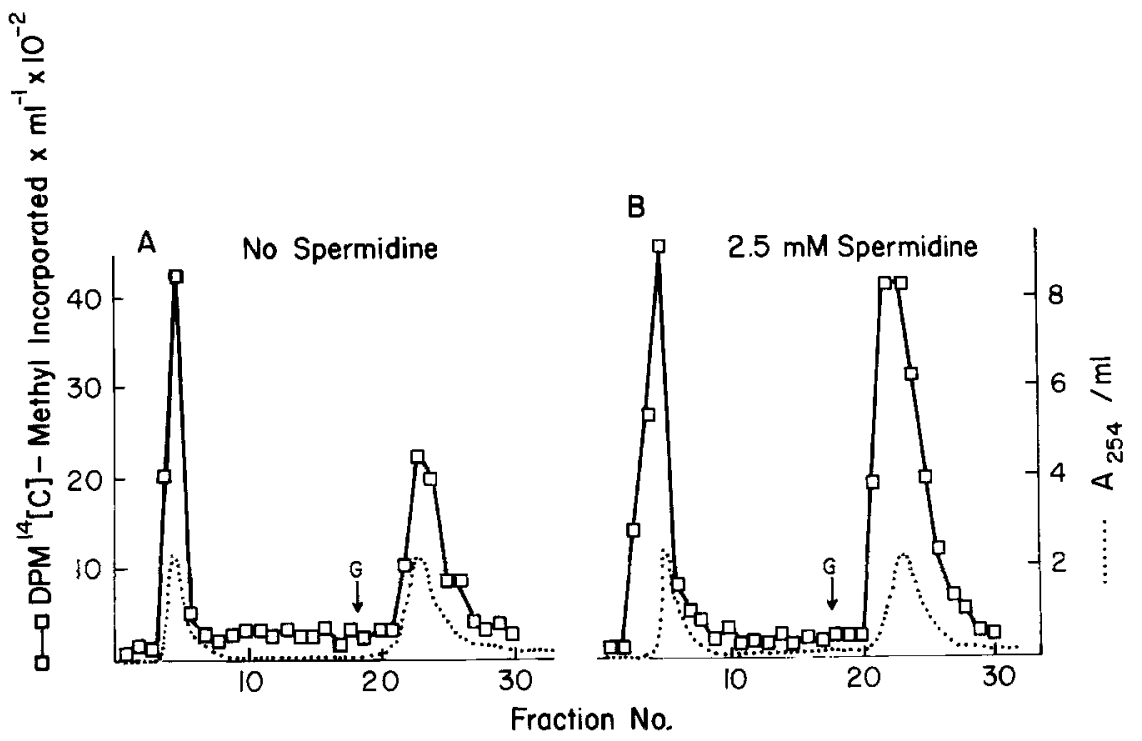

FIG. 6. DEAE-cellulose chromatography of the $\left[\mathrm{Me}-{ }^{14} \mathrm{C}\right]$ products formed by total methylation. The conditions of Fig. 5 apply, except that $E$. coli $B$ tRNA was added to the incubation (see Experimental Procedure). Spermidine: $2.5 \mathrm{mM}$.

function of postnatal age revealed that at 3 days, 1-methyl guanine was the major $\left[\mathrm{Me}-{ }^{14} \mathrm{C}\right]$ base, while at 18 days, this role was assumed by $\left[\mathrm{Me}^{14} \mathrm{C}\right] N^{2}$-methyl guanine. About $30 \%$ of the total radioactivity recovered from the TLC plates consisted of unidentified products irrespective of age.

\section{Nature of the $\left[\mathrm{Me}^{-14} \mathrm{C}\right]$ Bases Formed by Heterologous $t R N A$ Methylation}

The distribution of the $\left[\mathrm{Me}-{ }^{14} \mathrm{C}\right]$ bases formed under conditions of heterologous methylation is shown in Table III in which this distribution is compared with the pattern of heterologous methylation $(4,28)$ obtained in the absence of spermidine with nonneural tRNA methyltransferases. Inspection reveals the predominant formation of $\left[\mathrm{Me}^{-14} \mathrm{C}\right]$ $N^{2}$-methyl guanine, $N_{2}^{2}$-dimethyl guanine, and 1-methyl adenine, which accounted for about $85 \%$ of the total radioactivity, the remainder being identified as $\left[\mathrm{Me}^{-14} \mathrm{C}\right]$ 5-methyl cytosine, 5-methyl uracil, 2-methyl adenine, 1-methyl hypoxanthine, and 1-methyl guanine. No $\left[\mathrm{Me}-{ }^{14} \mathrm{C}\right] 7-$ methyl guanine could be detected. 
TABLE III

Distribution of $\left[\mathrm{Me}^{-14} \mathrm{C}\right]$ tRNA Bases After Heterologous Methylation By ENZYMES From DiffERent Sources

\begin{tabular}{lccc}
\hline & \multicolumn{3}{c}{ Percentage distribution $^{a}$} \\
\cline { 2 - 4 } \multicolumn{1}{c}{ Methylated constituent } & Rat brain $^{b}$ & Rat liver $^{b}$ & $\begin{array}{c}\text { Ascites tumor }_{\text {cells }}^{b} \\
\text { 1-Methylguanine }\end{array}$ \\
7-Methylguanine & 5.1 & 2 & 3.3 \\
$N^{2}$-Methylguanine & N.D. & 3 & 1.7 \\
$N_{2}^{2}$ - Dimethylguanine & 31.4 & 23 & 36.8 \\
5-Methylcytosine & 28.0 & 22 & 18.0 \\
5-Methyluracil & 2.2 & 7 & 15.8 \\
1-Methyladenine & 2.8 & 7 & $0.2^{d}$ \\
2-Methyladenine & 24.3 & 29 & 20.8 \\
1-Methylhypoxanthine & 3.3 & N.D. & N.D. \\
\hline
\end{tabular}

${ }^{a}$ Data are expressed as percentages of the total radioactivity recovered in the TLCseparated bases.

${ }^{b}$ Rat brain: present study; rat liver: ref. 3; ascites tumor: ref. 28.

${ }^{c}$ Not detected.

a 5-Hydroxymethyl uracil (28).

TABLE IV

Effect of Spermidine on the $\left[\mathrm{Me}^{-14} \mathrm{C}\right]$ Distribution of Total tRNA in Whole Brain Cortex and Isolated Nerve Cell Bodies

\begin{tabular}{|c|c|c|c|c|}
\hline \multirow[b]{3}{*}{ Methylated constituent } & \multicolumn{4}{|c|}{ Percentage distribution } \\
\hline & \multicolumn{2}{|c|}{ Whole cortex ${ }^{a}$} & \multicolumn{2}{|c|}{ Nerve cell bodies ${ }^{a}$} \\
\hline & - Spermidine & + Spermidine $^{b}$ & - Spermidine & + Spermidine \\
\hline 1-Methylguanine & 3.7 & 4.6 & 8.7 & 8.2 \\
\hline$N^{2}$-Methylguanine & 22.8 & 27.7 & 10.7 & 20.8 \\
\hline$N_{2}^{2}$-Dimethylguanine & 20.4 & 21.8 & 12.6 & 22.8 \\
\hline 5-Methylcytosine & 1.6 & 0.9 & N.D. ${ }^{c}$ & N.D. \\
\hline 5-Methyluracil & 1.8 & 0.8 & N.D. & N.D. \\
\hline 1-Methyladenine & 17.7 & 6.2 & 42.7 & 24.6 \\
\hline 2-Methyladenine & 2.4 & 1.5 & N.D. & N.D. \\
\hline 1-Methylhypoxanthine & 2.0 & 0.6 & N.D. & N.D. \\
\hline Unknown & 27.6 & 35.9 & 25.3 & 23.6 \\
\hline $\begin{array}{l}\text { Total dpm recovered from } \\
\text { TLC plate }\end{array}$ & 3,360 & 14,656 & 2,276 & 9,396 \\
\hline
\end{tabular}

${ }^{a}$ Eight-day-old animals were used.

b $2.5 \mathrm{mM}$.

${ }^{c}$ Not detected. 


\section{Effect of Brain Cell Type and of Spermidine on the $\left[\mathrm{Me}-{ }^{14} \mathrm{C}\right]$ Bases Formed by Heterologous Methylation}

A comparison of the effects of spermidine on the tRNA methyltransferases of the isolated nerve cell bodies with the enzymes of whole brain cortex (Table IV) revealed that, particularly in the nerve cell bodies, the polyamine caused an increase in the methylation of guanine and a decrease in the formation of 1-methyl adenine. The effect on the latter process was evident even at the level of the whole brain cortex and could be reproduced (data not shown) in 3-, 18-, and 43-day-old cortices, in addition to the 8-day-old ones shown. However, the most significant result shown in Table 4 was the marked shift toward 1-methyl adenine and away from $N^{2}$-methyl- and $N_{2}^{2}$-dimethyl guanine formation that was seen to accompany the methodological refinement in $\left[\mathrm{Me}-{ }^{14} \mathrm{C}\right]$ base analysis as it shifted from the level of the whole tissue to that of the neuron.

\section{DISCUSSION}

Immature brain tissue is characterized by a highly active RNA metabolism (29-31). Accordingly, it is to be expected that posttranscriptional modification reactions involving tRNA (30) play a major role during the early postnatal development of brain cells. The present study shows that the immature rat brain cortex contains methyltransferase enzymes that effectively catalyze the methylation of endogenous macromolecular acceptors, an observation that contrasts with previous reports $(4,6)$ of little, if any, endogenous methylation in the adult kidney (4) and brain (6). More recently, Johnson et al. (9) reported identical levels of endogenous protein methylation in neonatal and adult mouse brain.

As shown in Fig. 1, the addition of $E$. coli $B$ tRNA to 8-day-old cortical or neuronal high-speed supernatants resulted in a large increase of the transfer of $\left[\mathrm{Me}^{-14} \mathrm{C}\right]$ groups, a finding that confirms the presence in the immature rat brain of several highly active tRNA methyltransferases.

The different effects of spermidine on the endogenous and the $E$. coli $B$ tRNA methylations (Fig. 1 and Table I) were of particular interest. Thus, while the stimulation of heterologous tRNA methylation confirms previous reports of similar effects of the polyamine in nonneural systems $(3,4,13,14)$, the strong inhibition of endogenous methylation, especially in the brain of 3-day-old animals (Fig. 2), may be related to the 
presumed high and simultaneous demand for $S$-adenosyl-L-methionine by the rapidly developing activity of $S$-adenosyl-L-methionine decarboxylase (32). The similarity of the apparent $K_{m}$ values for $S$-adenosyl-Lmethionine of tRNA methyltransferases $(30,33)$ and of cerebral $S$ adenosyl-L-methionine decarboxylase $(34)\left(10^{-6}-10^{-5} \mathrm{M}\right)$ provides some support for this interpretation. Alternatively, spermidine could control selectively the methylation of neuronal, but not of the later maturing glial, tRNA's, an option supported indirectly by (1) the higher levels of spermidine in some, albeit not all, glia-rich brain regions (35); (2) the higher glial than neuronal levels of ornithine decarboxylase (EC 4.1.1.17), an essential enzyme in spermidine biosynthesis (36); and (3) the widely different $t R N A$ methyltransferase patterns exhibited by two different glial tumor cell lines (37).

Methylated albumin kieselguhr (MAK) and DEAE cellulose chromatography $(25,27)$ were employed to show that endogenous tRNA $(10$, 11) was methylated by homologous tRNA methyltransferases. It is of interest that homologous tRNA methylation was first described in adult rat liver (28) while the present study was in progress. The results of MAK chromatography (Fig. 4) show significant labeling of $A_{254}$-absorbing material, which was eluted together with the carrier $E$. coli $B$ tRNA (tubes 12-16), as well as substantial labeling of materials that were eluted after tRNA. Parallel chromatography of extracts derived from incubations containing $E$. coli $B$ tRNA (not shown) indicated a closely similar distribution of radioactivity.

In the course of the present study, we noted that addition of purified brain cortex tRNA to endogenous incubation mixtures resulted in no increased transfer of $\left[\mathrm{Me}^{-14} \mathrm{C}\right]$ groups over levels seen in controls from which purified brain tRNA was omitted. Simon et al. (6) briefly reported similar findings using adult whole rat brain; more recently, Jank and Gross (27) reported that addition of purified normal rat liver tRNA to a homologous methylation system resulted in a $25 \%$ increment of tRNA methylation. Our inability to influence homologous $t R N A$ methylation by the addition of purified, age-homologous brain tRNA signifies that the native tRNA's present in the high-speed cortical supernatant were more effective [ $\left.\mathrm{Me}^{-14} \mathrm{C}\right]$ acceptors than the purified tRNA. Whether this greater effectiveness was due to the removal, during the tRNA purification procedure, of a small but highly methyl-receptive fraction of precursor tRNA $(30,38,39)$ or to intrinsic differences in the binding of the tRNA methyltransferases to their "native" vs exogenous tRNA substrates, is difficult to ascertain at this time.

The pattern of $E$. coli $B$ tRNA methylation obtained in the absence of spermidine is shown in Table 3 , column 1 , and compared with patterns 
obtained with rat liver or ascites tumor cell enzymes $(3,28)$. Recently, Trottier (40) reported similar $E$. coli $K_{12}$ methylation patterns using brain as a source of the tRNA methyltransferases. In the present study, the following bases were methylated: $N^{2}$-methyl guanine, $N_{2}^{2}$-dimethyl guanine, 1-methyl adenine, 5-methyl cytosine, 5-methyl uracil, 2-methyl adenine, and 1-methyl-hypoxanthine. The apparent nonmethylation of 7 methyl guanine complements the findings of Leboy and Piester (13), who reported no methylation of $E$. coli $K_{12}$ tRNA 1- and 7-methyl guanine by hepatic tRNA methyltransferases, and those of Pegg (4), who showed that these residues accounted for no more than $5 \%$ of the total $\left[\mathrm{Me}^{-14} \mathrm{C}\right]$ incorporated into $E$. coli $B$ tRNA by liver enzymes.

The effect of spermidine on the $E$. coli $B$ methylation pattern (Table IV) was to decrease the $\left[\mathrm{Me}-{ }^{14} \mathrm{C}\right] 1$-methyl adenine contribution in the whole cortex and in the neurons, and to increase the $\left[\mathrm{Me}-{ }^{14} \mathrm{C}\right]$ guanine contribution, particularly in the neurons. Leboy and Piester (13) noted an opposite effect of spermidine in the liver-namely, a more than 2 -fold increase in $\left[\mathrm{Me}^{-14} \mathrm{C}\right] 1$-methyl adenine and a corresponding decrease in $\left[\mathrm{Me}-{ }^{14} \mathrm{C}\right]$ guanines. Pegg (4) reported that spermidine stimulates both [Me- $\left.{ }^{14} \mathrm{C}\right] 1$-methyl adenine and $N^{2}$-methyl guanine formation in liver. Table IV further shows that in the absence of spermidine, the neuronal contribution of $\left[\mathrm{Me}^{-14} \mathrm{C}\right] 1$-methyl adenine was more than twice that of the $\left[\mathrm{Me}^{-14} \mathrm{C}\right]$ guanines. This finding suggests an enrichment in the neuron of the 1-methyl adenine residue-specific tRNA methyltransferases $(33,41,42)$ and an impoverishment in guanine residue-specific tRNA methyltransferases $(33,43,44)$. An additional feature of interest shown in Table IV is the differential effect of spermidine on these two distinct families of residue-specific enzymes. Additional work is needed to clarify more accurately the cell-specific nature of tRNA methylation in brain cells and of the involvement of spermidine in this process.

\section{REFERENCES}

1. Klagsbrun, M. (1972) The contrast between the methylation of transfer ribonucleic acid in vivo and in vitro by normal and SV40 transformed $3 \mathrm{~T} 3$ cells. J. Biol. Chem. 247, 7443-7451.

2. STARr, J.L., and Sells, B.H. (1969) Methylated ribonucleic acids. Physiol. Rev. 49, 623-668.

3. PEgG, A.E., and Hawks, A.M. (1974) Further investigation of the increased transfer ribonucleic acid methylase activity in tumors of the mouse colon. Biochem. J. 137, 229-238.

4. PEGG, A.E. (1971) The effects of diamines and polyamines on enzymic methylation of nucleic acid. Biochim. Biophys. Acta 232, 630-642. 
5. Pegg, A.E. (1972) Methylation of yeast aspartic acid transfer RNA by rat liver extracts. FEBS Lett. 22, 339-342.

6. Simon, L.N., Glasky, A.J., and Rejal, T.H. (1967) Enzymes in the central nervous system: RNA methylase. Biochim. Biophys. Acta 142, 88-104.

7. Guroff, G., and Brodsky, M. (1971) Enzymes of nucleic acid metabolism in the brains of young and adult rats. J. Neurochem. 18, 2077-2084.

8. MeZEI, C., and Hu, Y.-W. (1972) The pattern of methylation of RNA in peripheral nerve of the chick during development. J. Neurochem. 19, 2071-2081.

9. Johnson, T.C., Mathews, R.A., and Chou, L. (1974) tRNA methyltransferase activity in neonatal and mature mammalian neural tissue. $J$. Neurochem. 23, 489-496.

10. Cummins, C.J., Salas, C.E., and Sellinger, O.Z. (1975) The homologous methylation of tRNA in rat brain. Brain Res. 96, 407-412.

11. Salas, C.E., and Sellinger, O.Z. (1975) Abstracts, 5th International Meeting of International Society for Neurochemistry, Barcelona, Spain, p. 277.

12. Bacharach, U. (1973) Polyamines and nucleic acids. In: Function of Naturally Occurring Polyamines, Academic Press, New York, London, pp. 63-73.

13. Leboy, P.S., and Piester, P. (1973) In vitro studies of RNA methylation in the presence of polyamines. In: Russell, D.H. (ed.), Polyamines in Normal and Neoplastic Growth, Raven Press, New York, pp. 103-110.

14. Russell, D.H., and MCVICKER, T.A. (1972) Polyamines in the developing rat and in supportive tissues. Biochim. Biophys. Acta 259, 247-258.

15. Seller, N., and LAMBerTy, U. (1975) Interrelations between polyamines and nucleic acids: Changes of polyamine and nucleic acid concentrations in the developing rat brain. J. Neurochem. 24, 5-13.

16. SeIler, N., and SchmidT-Glenewinkel, T. (1975) Regional distribution of putrescine, spermidine and spermine in relation to the distribution of RNA and DNA in the rat nervous system. J. Neurochem. 24, 791-795.

17. SANTI, D.V., and Webster, R.W., JR. (1975) The role of polyamines in the aminoacyl transfer ribonucleic acid synthetase reactions. J. Biol. Chem. 250, 3874-3877.

18. Matsuzaki, K., and TAKedA, Y. (1973) Aminoacyl transfer RNA formation. Mechanism of aminoacylation stimulated by polyamines. Biochim. Biophys. Acta 308, 339351 .

19. Igarashi, K., Takahashi, K., and Hirose, S. (1974) Necessity of polyamines for maximum isoleucyl-tRNA formation in rat liver cell-free system. Biochem. Biophys. Res. Commun. 60, 234-240.

20. TAKedA, Y., and MatsuZaki, K. (1974) Aminoacyl transfer RNA formation. Kinetic evidence of the concerted mechanism of isoleucyl-tRNA formation stimulated by spermine. Biochem. Biophys. Res. Commun. 59, 1302-1310.

21. Schreier, A.A., and Schimmer, P.R. (1975) Interaction of polyamines with fragments and whole molecules of yeast phenylalanine-specific transfer RNA. J. Mol. Biol. 93, 323-329.

22. TAKedA, Y., and OHNishi, T. (1975) Binding of transfer RNA to polyamines in preference to $\mathrm{Mg}^{+6}$. Biochem. Biophys. Res. Commun. 63, 611-617.

23. Sellinger, O.Z., Azcurra, J.M., Johnson, D.E., Ohlsson, W.G., and Lodin, Z. (1971) Independence of protein synthesis and drug uptake in nerve cell bodies and glial cells isolated by a new technique. Nature, London New Biol. 230, 253-256.

24. Furano, A.V. (1972) A very rapid method for washing large numbers of precipitates of proteins and nucleic acids. Anal. Biochem. 43, 639, 640.

25. Mandell, J.D., and Hershey, A.D. (1960) A fractionating column for analysis of nucleic acids. Anal. Biochem. 1,66-77. 
26. Lowry, O.H., Rosebrough, N.J., FarR, A.L., and Randall, R.J. (1951) Protein measurement with the Folin phenol reagent. J. Biol. Chem. 193, 265-275.

27. JANK, P., and Gross, H.J. (1974) Methyl-deficient mammalian transfer RNA: Homologous methylation in vitro of liver tRNA from normal and ethionine-fed rats: Ethionine effect on 5-methyl-cytidine synthesis in vivo. Nucleic Acids Res. 1, 12591268.

28. Liau, M.C., O'Rourke, M.C., and Hurlbert, R.B. (1972) Transfer ribonucleic acid methylases of nucleoli isolated from a rat tumor. Biochemistry 11, 629-636.

29. MANDEL, P.S., and JACOB, M. (1972) RNA metabolism. In: Lajtha, A. (ed.), Handbook of Neurochemistry, Vol. 5A, Plenum Press, New York, pp. 165-198.

30. Söll, D. (1971) Enzymatic modification of transfer RNA. Science 173, 293-299.

31. Azcurra, J.M., Sellinger, O.Z., and Carrasco, A.E. (1975) In vivo labelling of cytoplasmic RNA in neurons of the immature brain cortex. Brain Res. 86, 144-149.

32. Shaskan, E.G., Haraszti, J.H., and SnYder, S.H. (1973) Polyamines: Developmental alterations in regional disposition and metabolism in rat brain. $J$. Neurochem. $20,1443-1452$.

33. Glick, T.M., and LeBoy, P.S. (1975) $S$-adenosylhomocysteine inhibition of three purified tRNA methyltransferases from rat liver. Nucleic Acids Res. 2, 1639-1651.

34. Schmidt, G.L., and CANtoni, G.L. (1973) Adenosylmethionine decarboxylase in developing rat brain. $J$. Neurochem. 20, 1373-1385.

35. Kremzner, L.T. (1973) Polyamine metabolism in normal and neoplastic neural tissue. In: Russell, D.H. (ed.), Polyamines in Normal and Neoplastic Growth, Raven Press, New York, pp. 27-40.

36. Kremzner, L.T., Barrett, R.E., and Terrano, M.J. (1970) Polyamine metabolism in the central and peripheral nervous system. Ann. N.Y. Acad. Sci. 171, 735-748.

37. Brighetti, S., Casagrande, A., Cupello, A., and lazzarini, G. (1972) Metilasi del tRNA nel glioblastoma. Boll. Soc. Ital. Biol. Sper. 48, 979-982.

38. Munns, T.W., and Sims, H.F. (1975) Methylation and processing of transfer ribonucleic acid in mammalian and bacterial cells. J. Biol. Chem. 250, 2143-2149.

39. Daniel, V., Grimberg, J.I., and ZeEvi, M. (1975) In vitro synthesis of tRNA precursors and their conversion to mature size tRNA. Nature London 257, 193-197.

40. TrotTIER, B. (1974) La méthylation du tRNA: Etudes in vitro sur le cerveau et le foie des mammifères. Doctoral dissertation, Department of Biochemistry, Université Laval School of Medicine, Québec City, Québec, Canada, pp. 1-147.

41. Kuchino, Y., and Nishimura, S. (1974) Methylation of Escherichia coli transfer ribonucleic acids by adenylate residue-specific transfer ribonucleic acid methylase from rat liver. Biochemistry 13, 3683-3688.

42. Agris, P.F., Spremulli, L.L., and Brown, G.M. (1974) tRNA methylases from HeLa cells: purification and properties of an adenine-1-methylase and a guanine- $N^{2}$ methylase. Arch. Biochem. Biophys. 162, 38-47.

43. KRaus, J., and Staehelin, M. (1974) $N^{2}$-guanine specific transfer RNA methyltransferase I from rat liver and leukemic rat spleen. Nucleic Acids. Res. 1, 1455-1478.

44. Kraus, J., and Staehelin, M. (1974) $N^{2}$-guanine specific transfer RNA methyltransferase II from rat liver. Nucleic Acids Res. 1, 1479-1496. 